\title{
Communication model in the implementation of integrated cropping calendar information system in North Sumatra
}

\author{
Abdul Aziz ${ }^{1 *}$, Pudji Muljono ${ }^{2}$, Irsal Las ${ }^{3}$, Retno Sri Hartati Mulyandari ${ }^{4}$, and Yayan \\ Apriyana $^{5}$ \\ ${ }^{1}$ Research staff, Indonesian Agency for Agricultural Research and Development Secretariat, Jl. \\ Ragunan No. 29 Pasar Minggu, Jakarta Selatan, Indonesia \\ ${ }^{2}$ Lecturer, Faculty of Human Ecology, IPB university, Jln. Kamper Kampus IPB Darmaga, Bogor, \\ Indonesia \\ ${ }^{3}$ Researcher, Indonesian Center for Agricultural Land Resources Research and Development, \\ Cimanggu, Bogor, Indonesia \\ ${ }^{4}$ Secretary, Directorate General of Horticulture, Jl. AUP No. 3 Pasar Minggu Jakarta Selatan, \\ Indonesia \\ ${ }^{5}$ Indonesian Agroclimate and Hydrology Research Institute, Jl. Tentara Pelajar No. 1A Bogor
}

\begin{abstract}
Integrated Cropping Calendar Information System (ICCIS) is an application used to convey innovative research results related to cropping patterns, varieties, fertilization, pest attacks, agricultural tools and machinery. This study aims to identify the influencing factors and communication models in the implementation of ICCIS in the North Sumatra region. Data analysis uses the Partial Least Squares Structural Equation Modelling (PLS-SEM) method. The result showed that the ICCIS Task Force Team (TGT Katam), characteristics of farmers, and characteristics of ICCIS have positive effects on the level of implementation of ICCIS by farmers, with variable significance values of 3.902, 3.851, and 8,296 , respectively. In related to the level of application of ICCIS by farmers, the analysis results have a positive effect on the added value of the use of ICCIS with a significance value of 6.509. TGT Katam received ICCIS information from the central cropping calendar team and the technical implementation unit that oversees it. TGT Katam in the North Sumatra region delivered ICCIS information to farmers through socialization and demonstration plots. Interpersonal communication and the demonstration plot media encouraged farmers to implement ICCIS recommendations. Satisfy the local wisdom, compatibility, data accuracy, trialability, observability, and relative advantage are indicators that farmers can implement ICCIS.
\end{abstract}

* Corresponding author : ayizhar@yahoo.com 


\section{Introduction}

As an agricultural country, Indonesia has an agricultural land area of 60.2 million hectares, with average national rice productivity in 2020 reaching 5.11 tons per hectare. However, population growth which continues to increase every year, and the loss of agricultural areas due to land conversion have caused national rice production run into fluctuations and tend to decrease. North Sumatra is one of the provinces as the central rice producer in Indonesia, which in the $2018-2020$ period tend to decreased in rice production, from 2.1 million tons in 2018, 2.08 million tons in 2019 and 2.04 million tons in 2020 [1]. One of the factors contributing to the problem is the underutilization of modern technology in agriculture.

The Indonesian government's efforts to fulfil the national food needs, especially rice. The Ministry of Agriculture through the Agricultural Research and Development Agency (IAARD) develops information and communication technology by designing The Integrated Cropping Calendar Information System (ICCIS). The ICCIS is a website and Android-based application that functions as a tool for users, especially extension workers and farmers, to determine the proper planting time according to the agroecology in an area. In addition, ICCIS also recommends technology packages produced by the IAARD such as the varieties used, the use of balanced fertilizers, information on pests and diseases that will attack plants, the tools and agricultural tools and machinery to be used, the areas that are used, and potentially prone to flooding and drought. This system is also equipped with standing crop information that can monitor plant growth in real-time in the field.

The socialization of ICCIS nationally has been carried out to more than 200 Agricultural Extension Centre (BPP) [2]. Socialization activities for the use of ICCIS in North Sumatra are conveyed to extension workers by delivering them on each BPP and then socialized again to the farmer level. In 2014 the ICCIS was socialized to 33 districts in North Sumatra by researchers and agricultural extension agents at the North Sumatra Agricultural Technology Research Institute [3].

In general, the ICCIS technology transfer obtained by field agricultural extension agents (PPL) has not yet reached the farm level [2]. One of the obstacles is that farmers still carry out farming activities based on habits passed down from generation to generation. In addition, the ever-changing government policy in increasing rice production is an obstacle for extension workers to convey ICCIS to farmers. The emergence of policies to implement new technology seems to replace existing technology [4]. Therefore, this study aims to determine the factors that can influence farmers in implementing ICCIS and develop an effective communication model in implementing ICCIS at the farmer level in the North Sumatra region.

\section{Methodology}

This research was conducted with a quantitative approach supported by a qualitative approach. The quantitative approach is carried out by distributing questionnaires to respondents as a research instrument while the qualitative approach is carried out by interviewing several respondents to obtain descriptions that occur in the field.

The research was conducted in 2018 - 2019 in Deli Serdang, Langkat, and Serdang Bedagai Districts, North Sumatra Province. These locations are part of the areas that have received ICCIS socialization and are one of the largest contributors to rice production in North Sumatra.

Sampling of respondents in this study a number of 44 farmers carried out by purposive sampling by determining the criteria for farmers who have received ICCIS socialization. The data collected through questionnaires were then processed using excel and analyzed through 
Structural Equation Modeling - Partial Least Square (SEM-PLS). The model produced by the SEM-PLS is then tested for hypotheses through the t-statistical test.

SEM-PLS analysis requires that all variables must meet the goodness of fit evaluation to meet the model fit assessment. Furthermore, to fulfil the suitability assessment of the model, it must meet the convergent validity test (factor loading / outer loading values, average variance extracted (AVE), and communality), discriminant test (AVE root and latent variable correlation and cross-loading), as well as a reliability test consisting of from the value of Cronbach's alpha and composite reliability [5].

\section{Result and discussion}

In this study, the latent variables are divided into two parts, namely the independent and the dependent variables [6]. The independent variables used are government support (GS), environmental support (ES), extension support (EXS), researcher/task force team support (TFS), farmer characteristics (FC), social system (SS), communication channels (CC), and ICCIS technology characteristics (ITC). The dependent variable consists of ICCIS application (IA) and the added value of ICCIS utilization (AVI).

\subsection{Evaluation goodness of fit through SEM-PLS in the implementation of ICCIS in North Sumatera}

Convergent validity in this study can be seen in the outer loading value contained in Table 1 and the AVE and communality values shown in Table 2 . The outer loading value must be greater than or equal to 0.7 , while the AVE and communality values must be greater than 0.5 .

Table 1. Outer-loading/factor-loading value.

\begin{tabular}{|l|c|l|l|l|l|l|l|l|l|l|}
\hline & ES & TFS & GS & EXS & FC & ITC & AVI & CC & SS & IA \\
\hline ESagroecology & 0,908 & & & & & & & & & \\
\hline TFScompetence & & 0,959 & & & & & & & & \\
\hline $\begin{array}{l}\text { TFSeasy to } \\
\text { contact }\end{array}$ & & 0,947 & & & & & & & & \\
\hline $\begin{array}{l}\text { ESinternet } \\
\text { connect }\end{array}$ & 0,756 & & & & & & & & & \\
\hline GSpolicy & & & 0,946 & & & & & & & \\
\hline GSinstitutional & & & 0,856 & & & & & & & \\
\hline EXScompetence & & & & 0,960 & & & & & & \\
\hline EXSsocialization & & & & 0,952 & & & & & & \\
\hline FCcourage & & & & & 1,000 & & & & & \\
\hline ITCdataaccuracy & & & & & & 0,897 & & & & \\
\hline ITClocalwisdom & & & & & & 0,959 & & & & \\
\hline ITCprofit & & & & & & 0,979 & & & & \\
\hline ITCcompatibility & & & & & & 0,944 & & & & \\
\hline ITCobservability & & & & & & 0,978 & & & & \\
\hline ITCtriability & & & & & & 0,967 & & & & \\
\hline AVIproduction & & & & & & & 0,781 & & & \\
\hline AVIproductivity & & & & & & & 0,877 & & & \\
\hline CCinterpersonal & & & & & & & & 0,837 & & \\
\hline CCmass media & & & & & & & & 0,861 & & \\
\hline CCmedia use & & & & & & & & 0,875 & & \\
\hline SSsystem norm & & & & & & & & & 1,000 & \\
\hline IAintensity & & & & & & & & & & 0,982 \\
\hline IAsustainability & & & & & & & & & & 0,984 \\
\hline
\end{tabular}


Table 1 show that all outer loading/factor loading values on each variable have met the requirements, namely $\geq 0.7$. This data proves that the variables used in this study are convergent valid.

Table 2. Formatting sections, subsections and subsubsections.

\begin{tabular}{|l|l|c|}
\hline & AVE & communality \\
\hline ES & 0,698998 & 0.698998 \\
\hline TFS & 0,908927 & 0.908927 \\
\hline GS & 0,814632 & 0.814632 \\
\hline EXS & 0,915525 & 0.915525 \\
\hline FC & 1.000 .000 & 1.000 .000 \\
\hline ITC & 0,911676 & 0.911676 \\
\hline AVI & 0,690192 & 0.690192 \\
\hline CC & 0,736525 & 0.736525 \\
\hline SS & 1.000 .000 & 1.000 .000 \\
\hline IA & 0,967596 & 0.967596 \\
\hline
\end{tabular}

Table 2 provides information that all the variables used have met the goodness of fit requirements to be convergent valid because all variables have a value more than 0.5 .

Discriminant validity testing is done to ensure that each concept of each latent variable is different from other variables. The model is said to have good discriminant validity if each indicator loading value of a latent variable is more correlated with this latent variable than if it is correlated with other latent variables [7]. The AVE root value and the latent variable correlation in this test can be seen in Table 3 .

Table 3 shows that the root AVE value is greater than the latent variable correlation value that informs that the indicators contained in this study are valid. The discrimination test can also be done by looking at the cross-loading value. This value must be greater than 0.7 . The result of the cross-loading value is the same as the outer loading value shown in Table 1 above. The results of the SEM-PLS analysis show that the cross-loading value on the variable is $\geq 0.7$. This cross-loading value indicates that the variables used have met the goodness of fit.

Table 3. AVE root value dan correlation of variable laten.

\begin{tabular}{|l|c|c|c|c|c|c|c|c|c|c|c|}
\hline & ES & TFS & GS & EXS & FC & ITC & AVI & CC & SS & IA & $\begin{array}{c}\text { AVE } \\
\text { square }\end{array}$ \\
\hline ES & 1.000 & & & & & & & & & & 0,836 \\
\hline TFS & 0.580 & 1.000 & & & & & & & & & 0,953 \\
\hline GS & 0.602 & 0.868 & 1.000 & & & & & & & & 0,903 \\
\hline EXS & 0.546 & 0.643 & 0.694 & 1.000 & & & & & & & 0,957 \\
\hline FC & 0.677 & 0.583 & 0.777 & 0.572 & 1.000 & & & & & & 1000 \\
\hline ITC & 0.747 & 0.750 & 0.878 & 0.750 & 0.874 & 1.000 & & & & & 0,955 \\
\hline AVI & 0.569 & 0.543 & 0.468 & 0.393 & 0.510 & 0.606 & 1.000 & & & & 0,831 \\
\hline CC & 0.670 & 0.820 & 0.787 & 0.839 & 0.644 & 0.807 & 0.498 & 1.000 & & & 0,858 \\
\hline SS & -0.602 & -0.392 & -0.444 & -0.427 & -0.551 & -0.589 & -0.381 & -0.590 & 1.000 & & 1000 \\
\hline IA & 0.733 & 0.624 & 0.820 & 0.711 & 0.918 & 0.964 & 0.523 & 0.731 & -0.581 & 1.000 & 0,984 \\
\hline
\end{tabular}

To measure the reliability of the questionnaire given to these respondents in this study using Cronbach Alpha with the help of Smart PLS software. Reliability has been considered satisfactory if the coefficient reaches a minimum of $\mathrm{r} x y=0.900$. However, if the reliability coefficient obtained is not that high, it can still be significant in some instances. According 
to Guildford's criteria in [8], Cronbach's Alpha reliability coefficient is divided into the levels of very reliable $(0.900)$, reliable $(0.700-0.900)$, quite reliable $(0.400-0.700)$, less reliable $(0.200-0.400)$, and not reliable $(<0.200)$. To measure reliability, you can use alpha Cronbach's (AC) and composite reliability (CR). However, CR is considered better in estimating the internal consistency [9]. The results of variable reliability tests in this study can be seen in Table 4.

Table 4. Variable Reliability Test.

\begin{tabular}{|c|c|c|}
\hline & Cronbach's Alpha & Composite Reliability \\
\hline ES & 0.585772 & 0.821633 \\
\hline TFS & 0.900201 & 0.952289 \\
\hline GS & 0.783495 & 0.897617 \\
\hline EXS & 0.907910 & 0.955899 \\
\hline FC & 1.000 .000 & 1.000 .000 \\
\hline ITC & 0.980470 & 0.984096 \\
\hline AVI & 0.557093 & 0.816209 \\
\hline CC & 0.821146 & 0.893430 \\
\hline SS & 1.000 .000 & 1.000 .000 \\
\hline IA & 0.966535 & 0.983531 \\
\hline
\end{tabular}

Table 4 illustrates that the results of the variable reliability test in this study are good because the CR value of each variable has met the standard $>0.7$.

\subsection{Hypothesis testing}

Hypothesis testing is based on the values contained in the structural analysis of the model. The significance level of the path coefficient is obtained from the t statistical value and the standardized path coefficient value. Therefore, the limit of the value of hypothesis testing, namely the $t$ value of the factor loading, is greater than the critical value greater than 1.64. The following shows the value of the parameter coefficient in Figure 1.

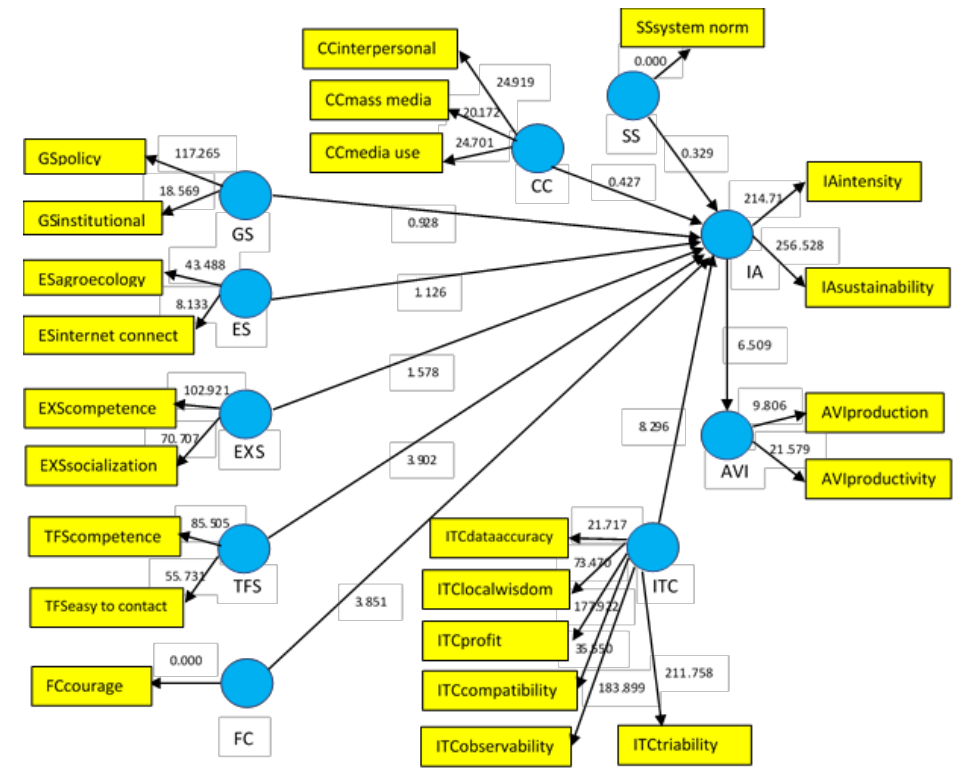

Fig. 1. Hypothesis test results of the communication model in the implementation of ICCIS in the North Sumatra region. 
Figure 1 shows that the variables with a positive effect have a coefficient value of $>1.64$ on the ICCIS Implementation Level, namely TFS with a coefficient value of 3.902; FC with a coefficient value of 3.851; and ITC with a coefficient value of 8,296. Then, the IA variable with a coefficient value of 6.509 positively affects ICCIS utilization (AVI).

\subsection{ICCIS communication model at farm level in North Sumatra}

Based on the results of hypothesis testing in the SEM-PLS analysis, some factors can affect the level of farmer implementation of ICCIS. Farmers can implement ICCIS because they support researchers at the North Sumatra Assessment Institutes for Agricultural Technology (AIAT) or what is commonly known as the ICCIS Task Force Team (TGT Katam). In addition, other factors that influence the implementation of farmers to ICCIS are the characteristics of farmers and the characteristics of ICCIS technology.

Communication is one of the very principal things in an organization because communication can influence other people to participate in achieving organizational goals $[10,11]$. There are many ways used in communicating to convey ideas and ideas to others. The communication built by Indonesian Agency for Agricultural Research and Development (IAARD) in conveying information on the results of research is carried out in a top-down manner which is an order to employees, work units (UK) and technical implementing units (UPT) under it, including North Sumatra AIAT [12]. This fact indicates that the communication used by IAARD tends to be one-way, so that user feedback is not optimal.

TGT Katam is a team that is legalized under the Head of IAARD to socialize and provide ICCIS assistance to stakeholders in the regions. TGT Katam at North Sumatra has conducted outreach to local governments, provincial and district agriculture agencies, extension workers (PPL), and farmers. Table 5 present the results of interviews with stakeholders as evidence.

Table 5. Supporting TGT Katam in implementation of ICCIS.

\begin{tabular}{|l|l|}
\hline Stakeholders & Interview result \\
\hline $\begin{array}{l}\text { Provincial } \\
\text { Agriculture Office }\end{array}$ & $\begin{array}{l}\text { "The first information about ICCIS was obtained through AIAT } \\
\text { and TGT Katam }\end{array}$ \\
\hline $\begin{array}{l}\text { District Agricultural } \\
\text { Service }\end{array}$ & $\begin{array}{l}\text { “...the District Agriculture Service received ICCIS information } \\
\text { from AIAT / TGT Katam ...”. }\end{array}$ \\
\hline PPL & "We obtained ICCIS information from AIAT / TGT Katam ....” \\
\hline Farmers & "PPL together with TGT Katam gave ICCIS socialization to \\
& farmer groups......
\end{tabular}

Table 5 illustrates the support from TGT Katam, who always provides outreach and assistance to stakeholders. The survey results showed that 56.82 percent of respondents stated that the TGT Katam had assisted farmers in implementing the ICCIS. TGT Katam's support is illustrated by the presence of competency indicators and contact ability. TGT Katam must have adequate competence so that when providing socialization and assistance, they will be more confident in their ability to master the ICCIS material. Most of the respondents, namely 52.27 percent, stated that the TGT Katam had quite good competence. Respondents stated that TGT Katam has extensive insight and information about ICCIS and is good at modern communication technology. Furthermore, TGT Katam must also be quickly contacted by stakeholders if there are problems that arise in the field. The survey results showed that 59.09 percent of respondents stated that the TGT Katam was easy to contact if farmers wanted to ask about problems in the field.

Farmer characteristics are a factor that influences the implementation of ICCIS at the farm level. The only indicator that describes the characteristics of farmers is the courage of the 
farmers in adopting ICCIS technology. The farmers' courage was due to the demonstration plot conducted by TGT Katam and PPL. After seeing the results of the demonstration plot using ICCIS technology that was producing relatively high, some farmers applied ICCIS technology on their land.

The characteristics of ICCIS technology are factors that can influence the level of ICCIS implementation by farmers. Farmers will apply ICCIS if the technology is easy to try or practice, easy to see, profitable for farmers, and farmers' habits or line with local wisdom, according to what farmers need, and accurate data. Technology must be easily tested by users so that it can attract farmers to apply it. The survey results stated that 59.09 percent of respondents always tried the recommendations suggested by ICCIS. This data indicates that the ease with which farmers can try out recommendations from ICCIS will influence farmers to adopt the technology. Ease of sight or observability is a level of ease of technology that users can see and easily observe to be applied by users [13]. The results showed that 65.91 percent of respondents said that ICCIS was easily seen and observed by farmers. Farmers became interested in ICCIS after seeing the success of the demonstration plot process in one farmer's land that other farmers quickly saw in the vicinity. If a technology is to be adopted by farmers, it must also be profitable for its users. The survey results show that 61.36 percent of farmers have benefited from the ICCIS. Farmers feel that they can find out the planting time and cropping pattern according to the conditions in their area, and the resulting production has increased compared to before using ICCIS.

Then what is no less important is that technology must be following the habits of users or local wisdom [14]. Farmers will adopt technology if the technology follows the customs and culture passed down from generation to generation. The survey results illustrated that most farmers, namely 59.09 percent, stated that local wisdom was compatible with ICCIS, so farmers were willing to take advantage of ICCIS. The level of conformity with user needs is also an indicator of the adoption of technology by users. Farmers will use ICCIS technology when it is needed. The survey results showed that most farmers, namely 59.09 per cent, stated that ICCIS followed the farmers' needs. This suitability is due to an increase in the production of agricultural products. The average increase in production in the North Sumatra region after implementing ICCIS is 27.34 percent [4]. Another indicator of technological characteristics is data accuracy. Accurate data reflects a technology that is continually updated and up to date. The more accurate the data submitted, the more it will increase the trust and adoption of farmers towards ICCIS. The survey results to respondents revealed that 52.27 percent of farmers stated that the data on ICCIS was accurate. This could happen because the ICCIS data is continually updated at least twice a year so users can accept the recommendations contained in ICCIS users.

The results of SEM analysis in Figure 1 show that the communication process in implementing ICCIS at the farmer level in the North Sumatra region is more supported by TGT Katam as a communicator. TGT Katam conveyed ICCIS messages to farmers through socialization and mentoring activities carried out face-to-face and demonstration plots. The communication model in ICCIS in North Sumatra can be seen in Figure 2. 


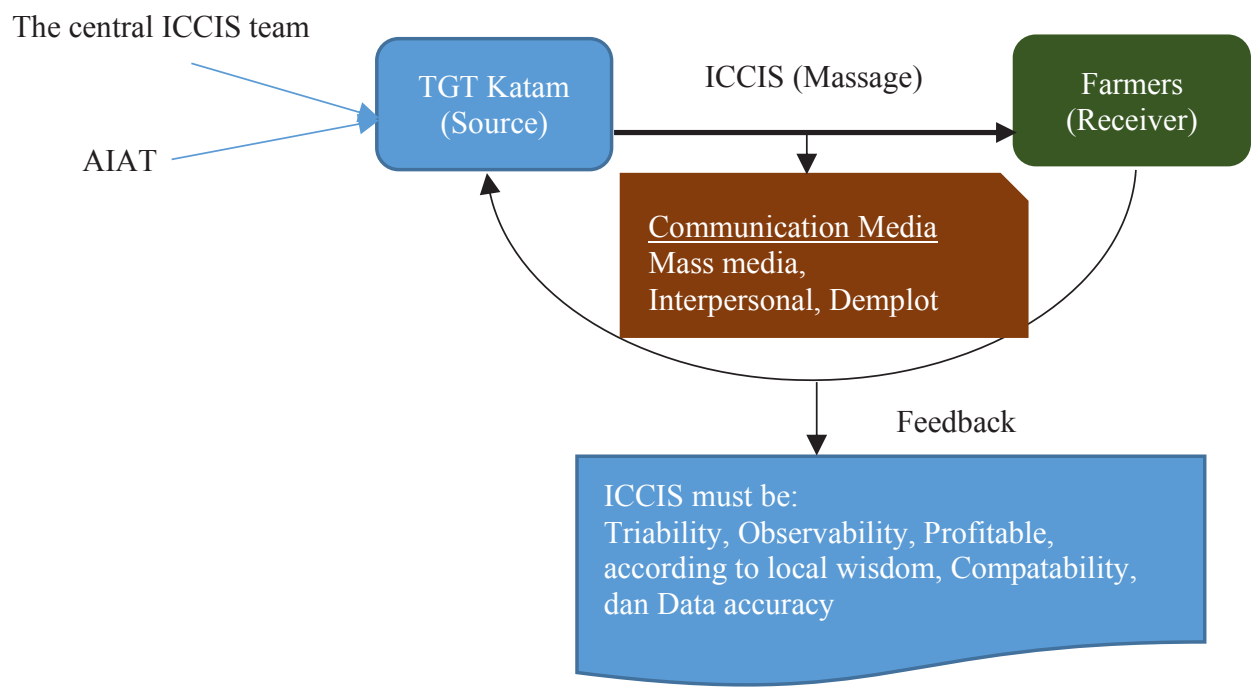

Fig. 2. Communication model in the implementation of ICCIS in North Sumatra.

North Sumatra AIAT obtained ICCIS information from IAARD through an official letter containing ICCIS technology dissemination to stakeholders in the North Sumatra region. The North Sumatra AIAT then followed up on the letter by giving the task to TGT Katam to provide outreach to the local government, the agriculture department, field agricultural extension workers (PPL), farmer groups, and farmers. TGT Katam is a team in the field formed by the Head of IAARD, whose duties are to disseminate and provide assistance to users in the North Sumatra region [15]. Apart from the Head of the North Sumatra AIAT, TGT Katam also received ICCIS information from the Central Katam Team. The results of an interview with TGT Katam North Sumatra stated that the TGT Katam throughout Indonesia was invited by the Central Katam Team to the IAARD office in Jakarta and Bogor to be given ICCIS socialization. Furthermore, TGT Katam conveyed the ICCIS information to farmers. The results of interviews with farmers in the Serdang Bedagai area revealed that:

"I took part in the socialization at BPP Sergai ... there were extension workers from AIAT (TGT Katam) ..."

After receiving socialization, technical guidance, and seeing the demonstration plot, the farmers applied ICCIS recommendations on their land. Farmers believe that what TGT Katam conveyed is a good thing and will increase their production results. The survey results of about 63.64 percent of respondents stated that they were sure of the recommendations made in the ICCIS. Farmers are aware and believe that ICCIS is a technology resulting from research that has been carried out and proven scientifically and with experience in the field.

Socialization, technical guidance, and assistance activities are carried out face-to-face with farmers. TGT Katam, together with PPL, visited farmer groups to provide information about ICCIS. In addition, the results of interviews with farmers stated that TGT Katam and PPL made demonstration plots on farmers' land.

The benefits of ICCIS can be seen from the feedback from users. Farmers who have implemented ICCIS can assess the strengths and weaknesses of ICCIS. Farmers consider the characteristics of ICCIS technology to be the primary key to be adopted by farmers. According to local wisdom, compatible, and accurate data, indicators that describe the characteristics of ICCIS so that farmers can use them are triability, observability, and beneficial to farmers. 


\section{Conclusions and recommendation}

This study concludes that the SEM-PLS analysis results indicate the goodness of fit or fit between variables. Furthermore, the variables that have been tested provide factors that can influence the implementation of ICCIS by farmers in the North Sumatra region, namely the support of TGT Katam with a coefficient value of 3.902; farmer characteristics with a coefficient value of 3.851; and ICCIS technology characteristics with a coefficient value of 8,296 .

The development of a communication model of ICCIS in North Sumatra is based on the results of the SEM-PLS analysis, which is adjusted to the factors that influence the implementation of ICCIS. This model was illustrated by TGT Katam, who provided ICCIS information to farmers. ICCIS information was provided through face-to-face outreach activities with farmers and making demonstration plots on farmers' land. As feedback from farmers so that users can use ICCIS, the characteristics of ICCIS technology must be trialability, observable, profitable, following local customs or wisdom, compatible, and have accurate data.

Suggestions that can be conveyed are to improve the quality and capacity of TGT Katam so that it can be more aggressively providing socialization and assistance to farmers. Besides, the role of PPL should be further enhanced so that farmers can easily get information and apply ICCIS.

\section{References}

1. Statistics of North Sumatera, Harvested Area, Production, and Productivity of Paddy by Regency/Municipality in Sumatera Utara Province, 2019 and 2020 (https://sumut.bps.go.id/statictable/2021/04/21/2285/luas-panen-produktivitas-danproduksi-padi1-menurut-kabupaten-kota-di-provinsi-sumatera-utara-2019-dan2020.html, 2021)

2. Indonesian Center for Agricultural Technology Assessment and Development, 2016 Annual Report of the Indonesian Center for Agricultural Technology Assessment and Development (ICATAD, 2016).

3. Suryani, Socialization of the Cropping Calendar in Asahan District (https://sumut. litbang.pertanian.go.id/index.php/en/info-aktual/177-sosialisasi-katam-di-kabupatenasahan, 2014)

4. A. Aziz, Development of innovation communication model in the implementation of integrated cropping calendar information systems (ICCIS) based on information technology (IPB University, 2020)

5. J.R. Hair, R.E. Anderson, R.L. Tatahm, W.C. Black, Multivariate Data Analysis (Upper Saddle River, NJ: Prentice Hall, 2006)

6. K.K. Wong, Marketing Bulletin 24, 1 (2013)

7. I.V. Karlita, Surati, M. Suryatni. International Journal of Multicultural and Multireligious Understanding 7, 11 (2020)

8. Sugiono, Statistic for research (Bandung (ID): Alfabet, 2010)

9. W.D. Salisbury, W.W. Chin, A. Gopal, P.R., Newsted, Information Systems Research 13, 1 (2002)

10. T.A. Gautama, Jurnal Sosiologi Dilema, 25, 2 (2010)

11. G. Bucata, A.M. Rizescu, Land Forces Academy Review, 22, 1(85) (2017)

12. A. Aziz, P. Muljono, I. Las, R.S.H. Mulyandari, Bioscience Research, 16, 3 (2019)

13. E.M. Rogers, Diffusion of Innovations. $5^{\text {th }}$ ed (New York: The Free express, 2003)

14. N.N.R. Suasih, I.A.N. Saskara, I.N.M. Yasa, M.K.S. Budhi, Journal of Sustainable Development, 10, 3 (2017) 
15. Indonesia Agricultural Agency Reseach and Development, Decree of the Head of the Agency for Agricultural Research and Development Number 178.1/Kpts/OT.160/ I/3/2012 concerning the Establishment of the Cropping Calendar and Climate Change Task Force at the Center for the Study of Agricultural Technology (Jakarta (ID): IAARD, 2012) 